\title{
1-MCP Improves Storability of 'Queen Cox' and 'Bramley' Apple Fruit
}

\author{
Paul T. Dauny \\ Cranfield University, Silsoe, Bedfordshire MK45 4DT, UK \\ Daryl C. Joyce \\ Institute for Horticultural Development, Agriculture Victoria, 621 Burwood \\ Highway, Victoria 3180, Australia
}

Additional index words. disease, Malus $\times$ sylvestris var. domestica, 1-methylcyclopropene, superficial scald, softening

\begin{abstract}
Better maintenance of firmness and suppression of ethylene production in 'Queen Cox' and 'Bramley' apple [Malus Xsylvestris (L.) Mill. var. domestica (Borkh.) Mansf.] fruit was achieved by prestorage applications of 1-MCP. 1-MCP concentration, exposure time and exposure temperature ranges of 0.1 to $10.0 \mu \mathrm{L}^{-1} \mathrm{~L}^{-1} \mathrm{1}-\mathrm{MCP}, 6$ to $48 \mathrm{~h}$, and 0 to $20^{\circ} \mathrm{C}$, respectively, were effective on fruit subsequently stored for 2 (' $\mathrm{Cox}$ ') and 3 ('Bramley') months in air at 3 to $4{ }^{\circ} \mathrm{C}$. However, 1-MCP had little effect on either firmness or ethylene production after 4 ('Cox') or 6 ('Bramley') months storage. Nonetheless, 1-MCP treated 'Bramley' fruit had reduced rot and superficial scald incidences compared with untreated control fruit. Chemical name used: 1-methylcyclopropene (1-MCP).
\end{abstract}

'Queen Cox' and 'Bramley' fruit [Malus $\times$ sylvestris (L.) Mill. var. domestica (Borkh.) Mansf.] are important apple cultivars, particularly in the U.K. 'Cox' is a dessert apple that softens quickly under retail conditions. 'Bramley' is a cooking apple that is susceptible to softening and development of the storage disorder superficial scald.

Maintenance of apple firmness is an aim of all apple storage management procedures, as soft fruit have reduced quality and commercial value. Softening is influenced by the internal ethylene concentration (IEC) of fruit. In general, firmness of fruit stored in ethylene concentrations below $44 \mu \mathrm{mol} \cdot \mathrm{m}^{-3}\left(1 \mu \mathrm{L} \cdot \mathrm{L}^{-1}\right)$ is greater than for those stored in higher ethylene concentrations (Stow et al., 2000). However, for 'Cox' fruit, removal of atmospheric ethylene only delayed the accumulation to a critical IEC level of $0.1 \mu \mathrm{L} \cdot \mathrm{L}^{-1}$ for 8 to 12 weeks. After this time, fruit softened; although less than for fruit stored in higher ethylene concentrations (Stow et al., 2000).

Superficial scald is a form of chilling injury of apple and pear fruit manifest as brown or discolored patches on the peel, with little or no physical damage to the pulp . Superficial scald is caused by the action of conjugated trienes (CTs) released as oxidative-breakdown products of $\alpha$-farnesene (Rupasinghe et al., 2000). Production of $\alpha$-farnesene in the skin tissue of apple fruit is influenced by ethylene levels in the fruit and storage atmosphere (Rupasinghe et al., 2000). Susceptibility to scald varies with cultivar, maturity, storage temperature and atmospheric ethylene levels (Huelin and Goggiola 1968, 1970).

Received for publication 9 July 2001. Accepted for publication 10 Feb. 2002. We thank Allen Hilton and AgroFresh, Inc. for their technical and financial support, respectively.
1-MCP binds to, and thus blocks, the ethylene receptor. As a result, ethylene is not able to bind to the receptor and exert an influence. 1-MCP treatment has been shown to reduce IEC (i.e., the suppression of autocatalytic ethylene production), maintain greater firmness, inhibit $\alpha$-farnesene production and reduce superficial scald development in 'Delicious', 'Law Rome' and 'McIntosh' apples (Rupasinghe et al., 2000; Watkins et al., 2000). In addition, 1-MCP has also been shown to suppress other ripening-associated changes in apples. Reduced respiration rate and lower total soluble solids (TSS) have been found in 1-MCP treated apple cultivars, including 'Gala', 'Jonagold' and 'Delicious'.

The aim of this work was to determine the efficacy of 1-MCP applied at a range of concentrations, durations of exposure and exposure temperatures in reducing superficial scald development in 'Bramley' and softening of 'Bramley' and 'Cox' fruit during storage at 3 to $4{ }^{\circ} \mathrm{C}$ in air. Knowledge of the efficacy of 1-MCP applied under these conditions will be useful when designing commercial utilization strategies.

\section{Materials and Methods}

'Cox' and 'Bramley' apple fruit were harvested from a farm in Plaxtol, Kent, U.K. over the Sept. to Oct. 2000 season. Fruit were randomized, labelled and weighed on the day of harvest, and treated within $24 \mathrm{~h}$ (Table 1). 'Cox' apples were dipped in $10 \mathrm{~g} \cdot \mathrm{L}^{-1} \mathrm{Ridomil}^{\mathrm{TM}}$ mbc 60WP [carbendazin $\left(5 \mathrm{~g} \cdot \mathrm{L}^{-1}\right)$ and metalaxyl (1 g. $\left.\left.\mathrm{L}^{-1}\right)\right]$ (Syngenta, Bracknell, U.K.) to control Phytophthora spp. 'Bramley' fruit were not dipped in fungicide, as per normal commercial practice. Fruit were equilibrated to treatment temperature and placed inside cardboard fruit trays $(59 \times 37 \times 14 \mathrm{~cm}$;
30 fruit per tray). The trays were placed inside rigid polypropylene fumigation chambers $(88$ $\times 59 \times 59 \mathrm{~cm})$. 1 -MCP was prepared according to the method of Macnish et al. (1999). Briefly, $5 \mathrm{~mL}$ of lithium diisopropylamide (LDA; Fluka, Buchs, Switzerland) was injected into a test tube flushed with $\mathrm{N}_{2}$. A $0.3-\mathrm{mL}$ aliquot of 3-chloro-2-methylpropene (CMP; Fluka) was injected into the test tube over a period of 15 to $30 \mathrm{~min}$ to produce the lithium salt of 1-MCP. The liquid and precipitate mixture was allowed to stand at room temperature for an additional 30 min with regular mixing using a vortex mixer. $\mathrm{LiCl}$ precipitated throughout this stage. Measured aliquots of the 1-MCPevolving stock solution were placed into the fumigation chambers, which were immediately sealed.

1-MCP concentrations were quantified using a Carlo Erba GC8340 gas chromatograph fitted with an EL 980 FID and a DP800 integrator (Thermoquest, Hertfordshire, U.K.). Oven and detector temperatures were $100^{\circ} \mathrm{C}$. The 2m-long stainless steel column was packed with Chromosorb PAW mesh range 80-100, liquid phase OV1701 30\% loading (Jones Chromatography, Mid Glamorgan, U.K.). $1-\mathrm{MCP}$ was calibrated against $10 \mu \mathrm{L} \cdot \mathrm{L}^{-1} \mathrm{n}$ butane (British Oxygen Co. Gases, Guildford, U.K.).

Three experiments were conducted for each cultivar. In the 1-MCP concentration experiment, fruit were exposed to $0.0,0.1,0.5,1.0$, or $10 \mu \mathrm{L} \cdot \mathrm{L}^{-1} 1-\mathrm{MCP}$ at either 0 or $20^{\circ} \mathrm{C}$ for 24 or $48 \mathrm{~h}$. In the 1-MCP exposure time experiment, fruit were exposed to $1.0 \mu \mathrm{L} \cdot \mathrm{L}^{-1} 1-\mathrm{MCP}$ for $6,12,24$, or $48 \mathrm{~h}$ at either 0 or $20^{\circ} \mathrm{C}$. In the 1-MCP exposure temperature experiment, fruit were exposed to $1.0 \mu \mathrm{L} \cdot \mathrm{L}^{-1} 1-\mathrm{MCP}$ at $0,5,10$, 15 , or $20^{\circ} \mathrm{C}$ for either 24 or $48 \mathrm{~h}$.

After 1-MCP treatment, fruit were removed from the fumigation chambers, re-randomized and individually enclosed in perforated polypropylene bags (15- $\mu \mathrm{m}$ thickness, 400$\mu \mathrm{m}$-diameter holes, five holes per $\mathrm{cm}^{2}$ [Cryovac 250 Y]; Cryovac, U.K.). Fruit were then kept in cardboard fruit trays $(59 \times 37 \times 14 \mathrm{~cm} ; 30$ fruit per tray) and stored in air at 3 to $4{ }^{\circ} \mathrm{C}$ and $>95 \% \mathrm{RH}$. Temperature was logged throughout the storage periods. 'Cox' apples were stored for 2 and 4 months, with one additional set for 6 months in the 1-MCP concentration experiment. 'Bramley' apple fruit were stored for 3 and 6 months. Upon removal from coldair storage, the fruit were taken out of their perforated bags and kept in a shelf-life room at $20{ }^{\circ} \mathrm{C}$ and $50 \%$ to $60 \%$ relative humidity $(\mathrm{RH})$ for 0,7 , and $14 \mathrm{~d}$.

In addition, 30 fruit were taken per harvest for maturity analysis (Table 1). Ten were analyzed $24 \mathrm{~h}$ after harvest. The remaining 20 fruit were placed in the shelf life room and 10 were taken for analysis after $7 \mathrm{~d}$. The remaining 10 were analyzed $14 \mathrm{~d}$ after harvest.

After each storage and shelf life time, fruit were weighed and skin color $\left(L^{*} a^{*} b^{*}\right)$ was measured using a CR200 colormeter (Minolta, Osaka, Japan). Fruit IEC was determined as described by Saltveit (1982). A 1.1-mm-diameter $\times 40$-mm-long stainless steel needle was inserted through the calyx and sealed in place 
Table 1. Harvest dates and maturities of 'Cox' and 'Bramley' apple fruit for each experiment $(\mathrm{n}=10)$.

\begin{tabular}{lcccc}
\hline $\begin{array}{l}\text { 1-MCP treatments } \\
\text { (experiment) }\end{array}$ & Cultivar & $\begin{array}{c}\text { Harvest date } \\
(\text { year 2000) }\end{array}$ & $\begin{array}{c}\text { Penetration force } \\
(\mathrm{N})\end{array}$ & $\begin{array}{c}\text { IEC } \\
\left(\mu \mathrm{L} \cdot \mathrm{L}^{-1}\right)\end{array}$ \\
\hline Concentration & Cox & 13 Sept. & $83.2 \pm 2.7$ & $0.5 \pm 0.3$ \\
& Bramley & 6 Sept. & $74.4 \pm 1.8$ & 0.0 \\
Exposure duration & Cox & 20 Sept. & $71.7 \pm 1.9^{\mathrm{z}}$ & $0.4 \pm 0.2^{\mathrm{z}}$ \\
& Bramley & 20 Sept. & $73.6 \pm 2.0$ & 0.0 \\
Exposure temperature & Cox & 27 Sept. & $66.5 \pm 2.0$ & $25.3 \pm 12.4$ \\
& Bramley & 4 Oct. & $68.2 \pm 1.8$ & $0.2 \pm 0.1$ \\
\hline
\end{tabular}

${ }^{\mathrm{z}}$ One missing value $(\mathrm{n}=9)$

with Blu-Tack ${ }^{\mathrm{TM}}$ (Bostic, Leicester, U.K.). A 3-mL gas sample was withdrawn slowly from the apple with a syringe. The ethylene concentration in $1 \mathrm{~mL}$ of this sample was quantified by GC. Fruit firmness was measured on opposite sides of peeled fruit using a Digital Force Gauge (Mecmesin, West Sussex, U.K.) fitted with a $10.0-\mathrm{mm}$-diameter flat end probe. The descent of the probe was controlled at $50 \mathrm{~mm} /$ min using the cross head of an Instron 1122 Universal Tester (Instron, Buckinghamshire, U.K.). The TSS of fruit juice extracted by crushing the flesh around the penetration holes with a wooden spatula was measured using a PR-1 digital refractometer (Atago, Tokyo). The number of fruit affected with disease or superficial scald was recorded.

All six experiments were $5 \times 2 \times 3$ factorial arrangements. In the $1-\mathrm{MCP}$ concentration experiment, $\mathrm{n}$ (number of fruit) $=20$ for 2 months stored 'Cox' and 3 months stored 'Bramley' fruit after $24 \mathrm{~h}$ exposure to $1-\mathrm{MCP}$ and $n=10$ for 4 and 6 months stored 'Cox' and 6 months stored 'Bramley' after 48 h 1-MCP exposure. In all other experiments, $n=10$ for each individual treatment. Batches of 10 fruit from each treatment were assessed 0,7 , and 14 $\mathrm{d}$ after removal from storage. All treatments were arranged in a completely randomized design (CRD). Data were subjected to analysis of variance (ANOVA) using Genstat 5.0 (IACR Rothanstead, U.K.).

\section{Results and Discussion}

1-MCP applied at 0.1 to $10.0 \mu \mathrm{L} \cdot \mathrm{L}^{-1}$ maintained fruit firmness for 2 and 3 months in 'Cox' and 'Bramley', respectively (Fig. 1 A and B). Firmness of 'Cox' treated with 10.0 $\mu \mathrm{L} \cdot \mathrm{L}^{-1} 1-\mathrm{MCP}$ was slightly greater than that at the other 1-MCP concentrations. The higher concentration gradient at $10 \mu \mathrm{L} \cdot \mathrm{L}^{-1} 1-\mathrm{MCP}$ might have enhanced diffusion of 1-MCP into the fruit. Moreover, it is possible that excess 1-MCP may be sorbed in some way by fruit tissue beyond saturation of ethylene-binding sites. If so, 1-MCP may be slowly released during storage, becoming available to bind to newly synthesized or regenerated ethylenebinding sites (Golding et al., 1998).

IEC for fruit exposed to 1-MCP was reduced relative to that of untreated fruit (Fig. $1 \mathrm{~A}$ and B). An exception was the IEC for 'Cox' treated with $10.0 \mu \mathrm{L} \cdot \mathrm{L}^{-1} 1-\mathrm{MCP}$ which increased compared with other 1-MCP concentrations.

Firmness and IEC of 'Cox' and 'Bramley' fruit were not affected by 1-MCP at 4 and 6 months and 6 months storage, respectively (data not shown). Loss of 1-MCP efficacy over time during storage is probably due to increasing availability of ethylene-binding sites in the fruit tissue (Macnish et al., 2000; Sisler and Serek, 1999). There is debate as to the nature of this increase. It may be that binding sites slowly release bound 1-MCP after a period of time (regeneration), that 1-MCP is slowly metabolized, that new binding sites are formed (synthesis), or a combination of these possibilities. Involvement of plant metabolism is suggested by an observation that Pelargonium peltatum $\mathrm{L}$. plants treated with $1 \mu \mathrm{L} \cdot \mathrm{L}^{-1}$ $1-\mathrm{MCP}$ for $2 \mathrm{~h}$ at $22^{\circ} \mathrm{C}$ and then grown at 12 , 21 , and $25^{\circ} \mathrm{C}$ maintained resistance to ethylene-induced petal abscission for longer at the lower temperature (Cameron and Reid, 2001). Retreatment of re-sensitized pelargonium plants with 1-MCP restored their resistance to ethylene.

'Cox' and 'Bramley' fruit were as firm after 2 and 3 month air storage, respectively, after just $6 \mathrm{~h}$ exposure to $1.0 \mu \mathrm{L} \cdot \mathrm{L}^{-1} 1-\mathrm{MCP}$ as after the longest exposure time of $48 \mathrm{~h}$ (Fig. 2 A and B). An absence of a differential exposure time effect suggests that 1-MCP rapidly permeates throughout apple fruit. As in the 1-MCP concentration experiment, differences in firmness and IEC for untreated and 1-MCP treated fruit were not significant $(P>0.05)$ (data not shown) for longer storage periods of 4 and 6 months for 'Cox' and 6 months for 'Bramley'.
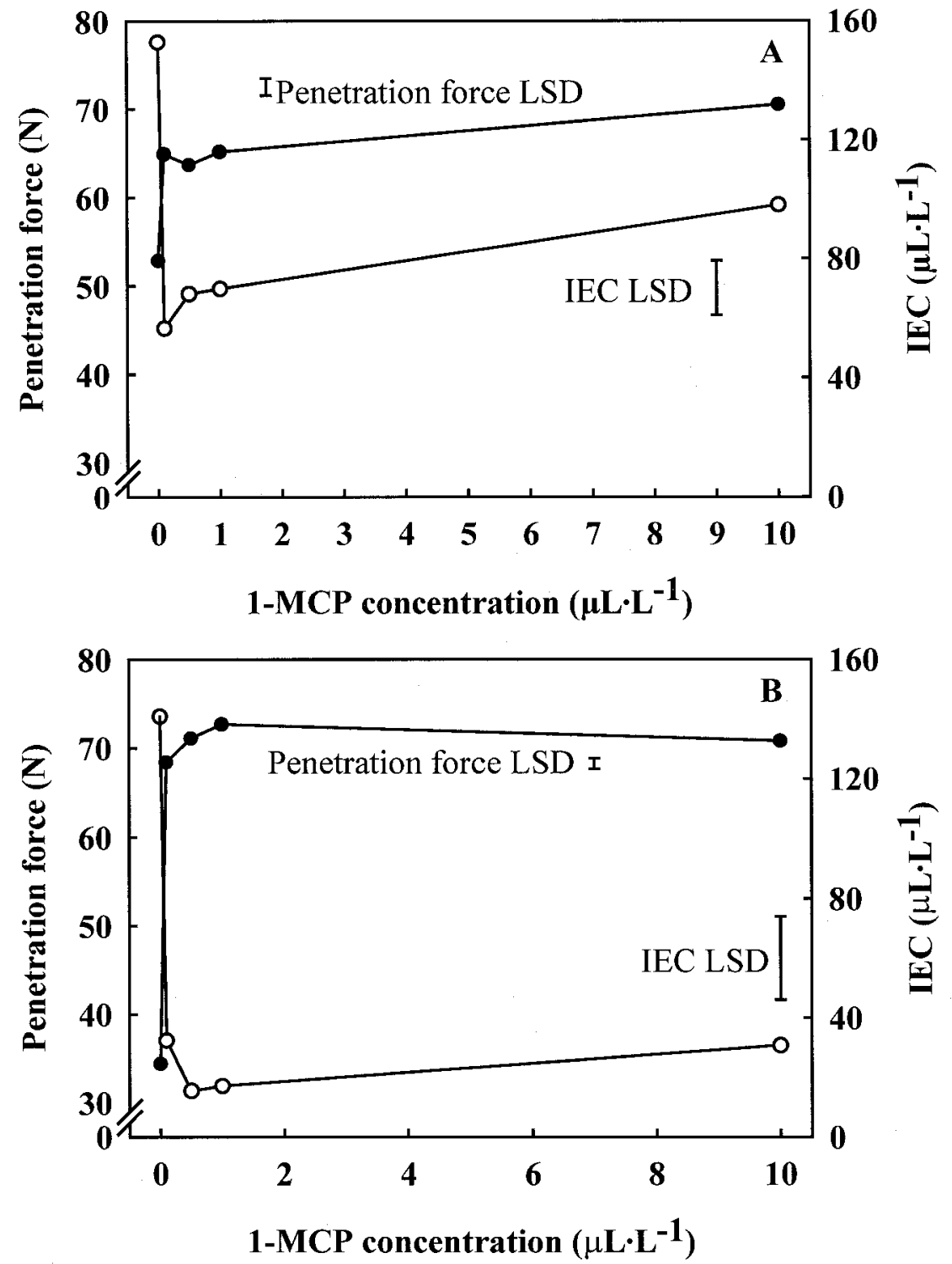

Fig. 1. Fruit firmness $(\bullet)$ and IEC $(\bigcirc)$ main factor means (i.e., across 0,7 , and $14 \mathrm{~d}$ shelf life evaluations) for apple fruit exposed to 1-MCP for $24 \mathrm{~h}$. Fruit were stored in air at 3 to $4{ }^{\circ} \mathrm{C}$ for 2 months ('Queen Cox', A) or 3 months ('Bramley', B). Data are the means for 60 individual replicate fruit. LSD $(P=0.05)$. 

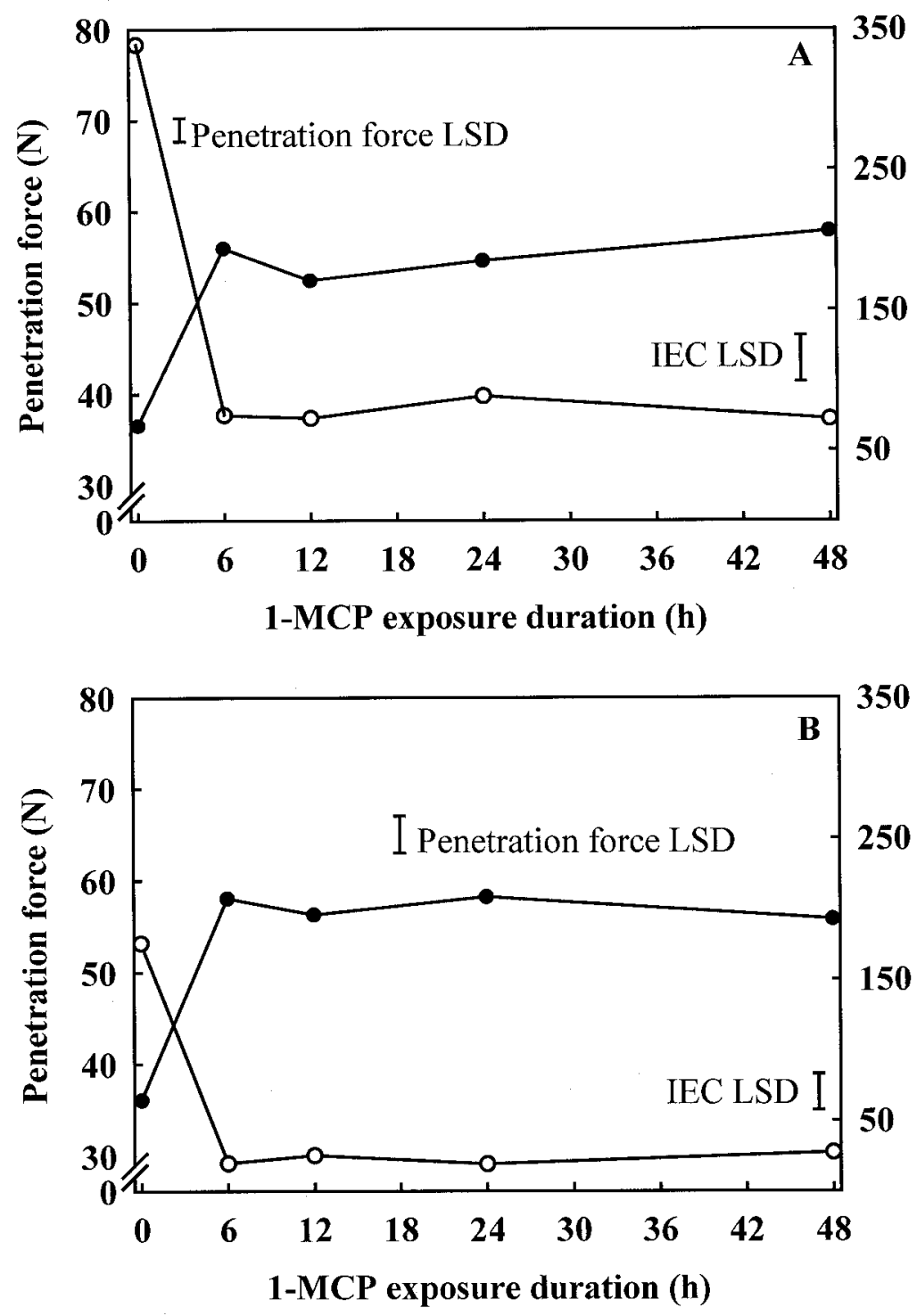

Fig. 2. Fruit firmness $(\bigcirc)$ and IEC $(\bigcirc)$ main factor means (i.e., across 0,7 , and $14 \mathrm{~d}$ shelf life evaluations) for apple fruit exposed to $1.0 \mu \mathrm{L} \cdot \mathrm{L}^{-1} 1-\mathrm{MCP}$ for different exposure times. Fruit were stored in air at 3 to $4{ }^{\circ} \mathrm{C}$ for 2 months ('Cox', A) or 3 months ('Bramley', B). Data are the means for 30 individual replicate fruit. $\operatorname{LSD}(P=0.05)$.

Table 2. Percentage of superficial scald and rot incidence in 'Bramley' apple fruit stored for 6 months in air at 3 to $4{ }^{\circ} \mathrm{C}$ with or without a prestorage 1-MCP application.

\begin{tabular}{lrr}
\hline $\begin{array}{l}\text { Parameter and } \\
\text { treatments (experiment) }\end{array}$ & Nontreated & 1-MCP treated \\
\hline & Superficial scald incidence & \\
1-MCP concentration & $17^{\mathrm{z}}$ & $1^{\mathrm{y}}$ \\
1-MCP exposure time & $32^{\mathrm{z}}$ & $0^{\mathrm{y}}$ \\
1-MCP exposure temperature & $1^{\mathrm{x}}$ & $1^{\mathrm{w}}$ \\
\multicolumn{4}{l}{$\begin{array}{l}\text { 1-MCP concentration } \\
\text { 1-MCP exposure time }\end{array}$} & Disease incidence & \\
1-MCP exposure temperature & $4^{\mathrm{z}}$ & $2^{\mathrm{y}}$ \\
\hline
\end{tabular}

${ }^{\mathrm{n}} \mathrm{n}=180$.

${ }^{y_{n}}=720$.

${ }^{\mathrm{x}} \mathrm{n}=150$

${ }^{\mathrm{w}} \mathrm{n}=300$.
Application temperature did not affect efficacy of 1-MCP on 'Cox' and 'Bramley' fruit after 2 and 3 months storage in air, respectively (Fig. 3 A and B). Thus, 1-MCP may be administered to 'Cox' and 'Bramley' apple fruit while in cold storage. This result is in agreement with work on banana fruit (Musa sp. 'Williams'; Cavendish subgroup AAA), grevillea 'Sylvia' (Grevillea banksii R. Brown $\mathrm{x}$ G. whiteana D.J. McGillivray) and Geraldton waxflower(Chamelaucium uncinatum Schauer) flowers (Macnish et al., 2000). 1-MCP efficacy at $0.1 \mu \mathrm{L} \cdot \mathrm{L}^{-1}$ was not affected at $2{ }^{\circ} \mathrm{C}$. However, at $0.01 \mu \mathrm{L} \cdot \mathrm{L}^{-1} 1-\mathrm{MCP}$, efficacy was reduced in the fruit and flowers at the lower temperature. Differences in firmness and IEC between control and 1-MCP treatments were nonsignificant $(P>0.05)$ (data not shown) for longer storage periods of 4 and 6 months for 'Cox' and 6 months for 'Bramley'.

1-MCP treatment prevented superficial scald development in 'Bramley' fruit after 6 months storage in both the 1-MCP concentration experiment and the 1-MCP exposure time experiment (Table 2). Inhibition of scald development in 'Bramley' by 1 -MCP confirms similar findings for 'Delicious', 'Granny Smith', 'Law Rome', and 'McIntosh' (Fan et al., 1999a, 1999b; Watkins et al., 2000). Scald incidence was $<1 \%$ in the 1 -MCP exposure temperature experiment. This overall reduction in scald compared with the preceding 1-MCP concentration and exposure time experiments may have been due to the later harvest of these fruit (Table 1). Similarly, a fruit maturity effect on scald development has been reported for 'Cortland', 'Delicious', 'Granny Smith', and 'Crofton' (Huelin and Coggiola, 1968; Watkins et al., 1993).

Disease incidence was low in both 'Cox' and 'Bramley' fruit following storage for 2 and 3 months, respectively (data not shown). Nonetheless, storage disease incidence in 'Bramley' was reduced by 1-MCP application regardless of the 1-MCP concentration, exposure time, or exposure temperature (Table 2). Proportionally greater disease incidence in both 1-MCP treated and control fruit was observed in the final 1-MCP exposure temperature experiment compared to the two earlier experiments. This tendency for more disease in the last 'Bramley' experiment may have been a feature of lower inherent disease resistance in late harvested fruit. Immature apple fruit are relatively resistant to diseases, and subsequently lose this resistance during maturation and ripening (Ndubizu, 1976). Reduced decay in association with 1-MCP treatment of 'Bramley' apple fruit contrasts with some other 1-MCP studies. For avocado, custard apple, mango, orange, papaya, and strawberry fruit, certain 1MCP treatments enhanced disease compared to untreated controls (Hofman et al., 2001; Jiang et al., 2001; Ku et al., 1999; Porat et al., 1999).

For both 'Cox' and 'Bramley', 1-MCP treatment resulted in slightly $(P<0.05)$ higher TSS $\left(\approx 1^{\circ}\right.$ Brix $)$ and reduced weight loss $(\approx 2 \%$ in real terms) compared with untreated control fruit (data not shown). There were no significant $(P$ $>0.05$ ) effects of 1-MCP on peel color (data not shown). 

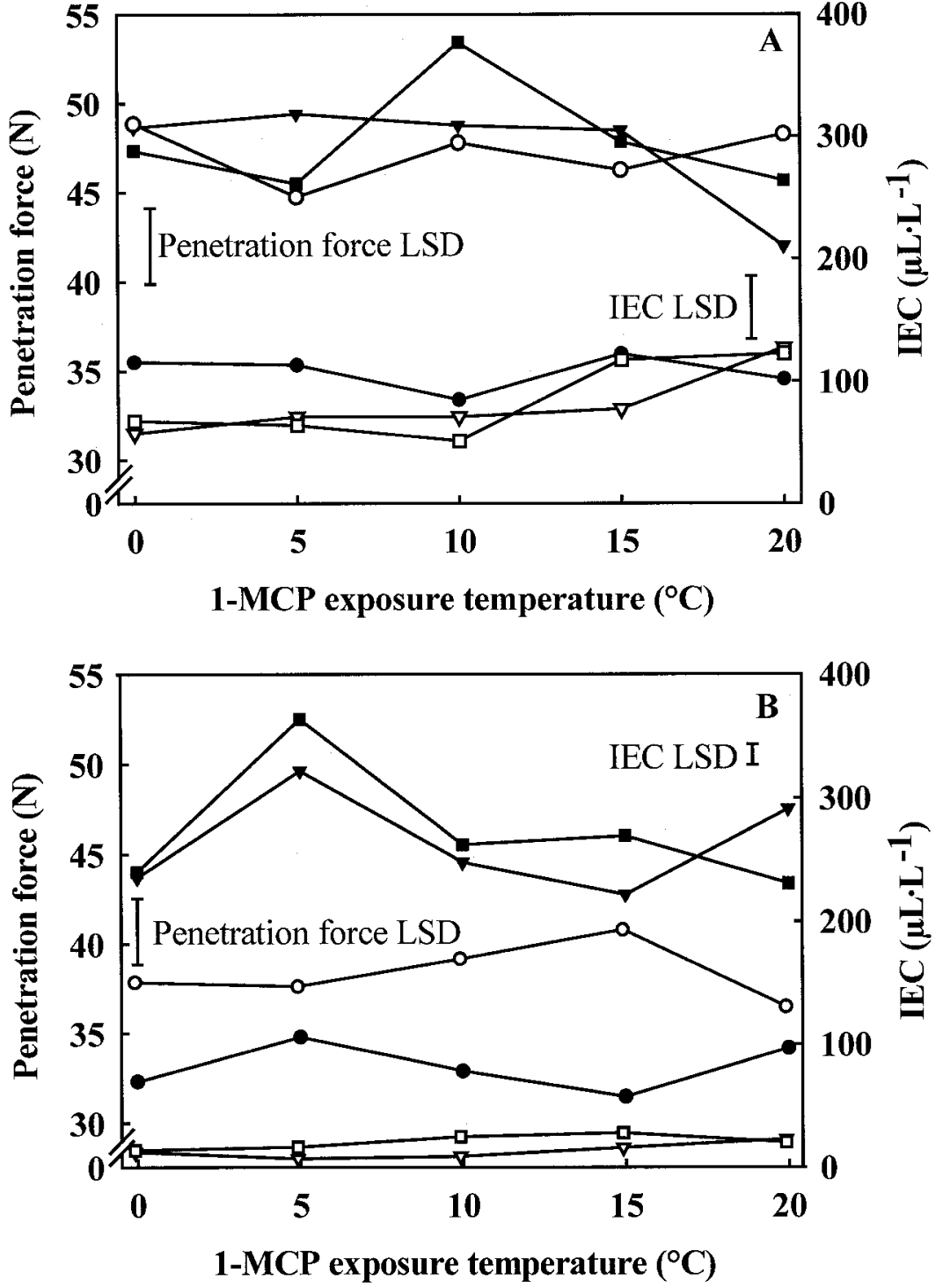

Fig. 3. Fruit firmness (closed symbols) and IEC (open symbols) main factor means (i.e., across 0,7 , and $14 \mathrm{~d}$ shelf life evaluations) for apple fruit exposed to $1.0 \mu \mathrm{L} \cdot \mathrm{L}^{-1} 1-\mathrm{MCP}$ at different temperatures for $0(\boldsymbol{\bullet}, \mathrm{O}), 24(\boldsymbol{\nabla}, \nabla)$ or $48 \mathrm{~h}(\boldsymbol{\square}, \square)$. Fruit were stored in air at 3 to $4{ }^{\circ} \mathrm{C}$ for 2 months ('Cox', A) or 3 months ('Bramley', B). Data are the means for 30 individual fruit. LSD $(P=0.05)$.

In summary, 1-MCP enhanced storability for 'Cox' and 'Bramley' apple fruit. Fruit firmness was better retained, disease incidence was reduced, and, for 'Bramley' fruit, superficial scald was inhibited. 1-MCP treatments ranging over 0.1 to $10 \mu \mathrm{L} \cdot \mathrm{L}^{-1}$ applied for 6 to $48 \mathrm{~h}$ at 0 to $20^{\circ} \mathrm{C}$ were effective.

\section{Literature Cited}

Cameron, A.C. and M.S. Reid, 2001. 1-MCP blocks ethylene-induced petal abscission of Pelargonium peltatum but the effect is transient. Postharvest Biol. Technol. 22:169-177.
Fan, X., J.P. Mattheis, and S. Blankenship. 1999a. Development of apple superficial scald, soft scald, core flush, and greasiness is reduced by MCP. J. Agr. Food Chem. 47:3063-3068.

Fan, X., S. Blankenship, and J.P. Mattheis. 1999b. 1-Methylcyclopropene inhibits apple ripening. J. Amer. Soc. Hort. Sci. 124:690-695.

Golding, J.B., D. Shearer, S.G. Wyllie, and W.B. McGlasson. 1998. Application of 1-MCP and propylene to identify ethylene-dependent ripening processes in mature banana fruit. Postharvest Biol. Technol. 14:87-98.

Hofman, P.J., M. Jobin-Décor, G.F. Meiburg, A.J. Macnish, and D.C. Joyce. 2001. Ripening and quality responses of avocado, custard apple, mango and papaya fruit to 1-methylcyclopropene. Aust. J. Expt. Agr. 41:567-572.

Huelin, F.E. and I.M. Coggiola. 1968. Superficial scald, a functional disorder of stored apples. IV. Effect of variety, maturity, oiled wraps and diphenylamine on the concentration of $\alpha$-farnesene in the fruit. J. Sci. Food Agr. 19:297-301.

Huelin, F.E. and I.M. Coggiola. 1970. Superficial scald, a functional disorder of stored apples. VII. Effect of applied $\alpha$-farnesene, temperature and diphenylamine on scald and the concentration and oxidation of $\alpha$-farnesene in the fruit. J. Sci. Food Agr. 21:584-589.

Jiang, Y., D.C. Joyce, and L.A. Terry. 2001. 1MCP treatment effects on strawberry fruit decay. Postharvest Biol. Technol. 23:227-232.

Ku, V.V.V., R.B.H. Wills and S. Ben-Yehoshua. 1999. 1-Methylcyclopropene can differentially affect the postharvest life of strawberries exposed to ethylene. HortScience 34:119-120.

Macnish, A.J., D.C. Joyce, P.J. Hofman, and D.H. Simons. 1999. Involvement of ethylene in postharvest senescence of Boronia heterophylla flowers. Aust. J. Expt. Agr. 39:911-913.

Macnish, A.J., D.C. Joyce, P.J.Hofman, D.H. Simons, and M.S. Reid. 2000.1-Methylcyclopropene treatment efficacy in preventing ethylene perception in banana fruit and grevillea and waxflower flowers. Aust. J. Expt. Agr. 40:471-481.

Ndubizu, T.O.C. 1976. Relations of phenolic inhibitors to resistance of immature apple fruits to rot. J. Hort. Sci. 51:311-319.

Porat, R., B. Weiss, L. Cohen, A. Daus, R. Goren, and S. Droby. 1999. Effects of ethylene and 1methylcyclopropene on the postharvest qualities of 'Shamouti' oranges. Postharvest Biol. Technol. 15:155-163.

Rupasinghe, H.P.V., D.P. Murr, G. Paliyath, and L. Skog. 2000. Inhibitory effect of 1-MCP on ripening and superficial scald development in 'McIntosh' and 'Delicious' apples. J. Hort. Sci. Biotech. 75:271-276.

Saltveit, M.E. 1982. Procedures for extracting and analyzing internal gas samples from plant tissues by gas chromatography. HortScience $17: 878-881$

Sisler, E.C. and M. Serek. 1999. Compounds controlling the ethylene receptor. Bot. Bul. Acad. Sin. 40:1-7.

Stow, J.R., C.J. Dover, and P.M. Genge. 2000. Control of ethylene biosynthesis and softening in 'Cox's Orange Pippin' apples during lowethylene, low-oxygen storage. Postharvest Biol. Technol. 18:215-225.

Watkins, C.B., C.L. Barden, and W.J. Bramlage. 1993. Relationships between alpha-farnesene, ethylene production and superficial scald development in apples. Acta Hort. 343:155-160.

Watkins, C.B., W.J. Bramlage, and B.A. Cregoe. 1995. Superficial scald of 'Granny Smith' apples is expressed as a typical chilling injury. J. Amer. Soc. Hort. Sci. 120:88-94.

Watkins, C.B., J.F. Nock, and B.D. Whitaker. 2000. Responses of early, mid and late season apple cultivars to postharvest application of 1methylcyclopropene (1-MCP) under air and controlled atmosphere storage conditions. Postharvest Biol. Technol. 19:17-32. 